KHAZANAH MULTIDISIPLIN

VOL 1 NO 12020

https://journal.uinsgd.ac.id/index.php/km

\title{
EFEKTIFITAS PENERAPAN ATURAN PILKADA SERENTAK 2020 DALAM KONDISI DARURAT PENANGANAN PENCEGAHAN PENYEBARAN CORONA VIRUS DISEASE 19 (COVID-19)
}

\author{
Siti Nani Aisyah \\ Ilmu Hukum, Pascasarjana UIN Sunan Gunung Djati Bandung, Indonesia \\ Email: sitinaniaisyah@gmail.com
}

\begin{abstract}
Public safety fundamental must be prioritized above the fundamental of election. The implementation of quality Regional Elections does not go straight with the results of quality leaders, for this reason public safety priorities in the Election 2020 in the conditions of the Covid-19 pandemic must be a priority. Based on this, the author intends to discuss the effectiveness of the implementation of Regional Election regulations in the pandemic conditions of the Covid-19. This study uses a qualitative method with a statue approach. If the results of multi-aspect simulations and predictions of pandemic's control will improve by the end of 2020, the Regional Election should be postponed by mid-2021, and for some Head Regional whose term of office has expired, they will be appointed as functionary.
\end{abstract}

Keywords: Covid-19, Head Regional, Pandemic, Regional Election 2020

\begin{abstract}
ABSTRAK
Prinsip keselamatan masyarakat harus dikedepankan bahkan di atas azas prinsip pemilihan. Penyelenggaraan Pemilihan Kepala Daerah yang berkualitas tidak berjalan lurus dengan hasil pemimpin yang berkualitas, untuk itu prioritas kesehatan masyarakat dalam Pemilihan Serentak Tahun 2020 dalam kondisi wabah Covid-19 harus menjadi prioritas. Berdasarkan hal tersebut Penulis bermaksud membahas berkaitan dengan efektifitas penerapan peraturan Pilkada dalam kondisi pandemi wabah Covid-19. Penelitian ini menggunakan metode kualitatif dengan pendekatan perundang-undangan (statue approach). Peniliti menguraikan bahwa penyelenggaraan Pemilihan Kepala Daerah yang berkualitas tidak berjalan lurus dengan hasil pemimpin yang berkualitas, untuk itu prioritas kesehatan masyarakat dalam Pemilihan Serentak Tahun 2020 dalam kondisi wabah Covid-19 harus menjadi prioritas. Jika, hasil simulasi multi aspek dan prediksi pengendalian pandemi akan membaik pada akhir 2020, sebaiknya Pilkada dapat diundur pada pertengahan 2021, dan untuk beberapa Kepala Daerah yang habis masa jabatannya ditunjuk Penjabat.
\end{abstract}

Kata Kunci : Covid-19, Kepala Daerah, Pandemi, Pilkada Serentak 2020 
KHAZANAH MULTIDISIPLIN

VOL 1 NO 12020

https://journal.uinsgd.ac.id/index.php/km

\section{PENDAHULUAN}

Keadaan dunia di tahun 2020 ini sedang mengalami pandemi global penyebaran Corona Virus Disease 19 atau lebih dikenal dengan Covid-19. Tak luput juga di Indonesia pun terkena dampak penyebaran virus ini. Mengutip Kennedy \& Suhendarto (2020, hlm. 2), bahwa Organisasi Kesehatan Dunia atau World Health Organization (WHO) mengumumkan Covid- 19 sebagai pandemi global pada tanggal 11 Maret 2020 (World Health Organization, 2020). Kurang lebih selama 6 (enam) bulan sejak Bulan Maret hingga Agustus 2020, Indonesia berada dalam kondisi tidak seperti biasanya, yakni dengan berlakunya Pembatasan Sosial Berskala Besar (PSBB), yang melarang aktivitas masyarakat di luar rumah. Dalam kondisi ini, banyak dampak yang dialami oleh seluruh elemen bangsa, baik Pemerintah juga masyarakat. Salah satu dampak dari adanya PSBB pada bulan 1Maret Tahun 2020 ialah adanya penundaan tahapan Pilkada Serentak Tahun 2020.

Menurut Kennedy dan Suhendarto (2020, hlm. 1) kondisi saat ini menyebabkan Pilkada 2020 mengalami penjadwalan ulang. Pemerintah bersama KPU dan DPR setuju menunda pelaksanaan Pilkada 2020 hingga bulan Desember 2020, hal ini diumumkan dalam Perppu No. 2 Tahun 2020. Konsekuensi dalam situasi ini, Pilkada 2020 berpotensi kembali diatur ulang penjadwalannya, serta posisi kepala daerah di beberapa wilayah pun mengalami kekosongan. Berdasarkan Peraturan Komisi Pemilihan Umum (KPU) Nomor 15 Tahun 2019 tentang Tahapan, Program dan Jadwal Penyelenggaraan Pemilihan Gubernur dan Wakil Gubernur, Bupati dan Wakil Bupati, dan/atau Walikota dan Wakil Walikota Tahun 2020, disebutkan bahwa pelaksanaan Pilkada Serentak Tahun 2020 seharusnya dilaksanakan pada hari Rabu tanggal 23 September 2020, sebagaimana telah tentukan demikian.

Selanjutnya, KPU sebagai penyelenggara Pemilihan Umum mengeluarkan Keputusan Nomor 179/PL.02- Kpt/o1/KPU/Ill/2020 
KHAZANAH MULTIDISIPLIN

VOL 1 NO 12020

https://journal.uinsgd.ac.id/index.php/km

tentang Penundaan Tahapan Pemilihan Gubernur dan Wakil Gubernur, Bupati dan Wakil Bupati, dan/atau Wali Kota dan Wakil Wali Kota Tahun 2020 dalam Upaya Pencegahan Penyebaran Covid -19 (Wasisto \& Prayudi, 2020, hlm. 26). Dalam surat keputusan seperti yang disebutkan di atas, disampaikan bahwa dalam rangka merespon situasi penyebaran wabah penyakit Covid-19 di Negara Kesatuan Republik Indonesia (NKRI) serta atas dasar pernyataan resmi WHO dan pernyataan resmi yang dikeluarkan oleh Presiden Joko Widodo. Presiden menyatakan kekhawatiran penyebaran Covid-19 yang termasuk dalam bencana nasional, maka KPU dipandang perlu menetapkan keputusan penundaan tahapan Pemilihan Gubernur dan Wakil Gubernur, Bupati dan Wakil Bupati, dan/atau Wali Kota dan Wakil Wali Kota Tahun 2020.

Dalam penelitian lainnya, oleh Hasibuan (2020, hlm. 123) menyebutkan memprediksi isi pemahaman materinya, keputusan tersebut hanya dibatasi pada penundaan penyelenggaraan teknis Pilkada sampai tahap penetapan daftar pemilih, namun tahapan penyeleggaran Pilkada serentak tetap akan dilaksanakan pada September 2020. Ketentuan tersebut disandarkan kepada maklumat yang tertuang dalam Pasal 201 ayat (6) Undang-Undang Nomor 10 Tahun 2016 tentang perubahan kedua atas UU Nomor 1 Tahun 2015 tentang Pemilihan Gubernur, Bupati, dan Walikota.

Demi pertimbangan keselamatan dan kesehatan masyarakat, Pemerintah yang diwakili oleh Menteri Dalam Negeri (Mendagri), Dewan Perwakilan Rakyat (DPR), KPU, Badan Pengawas Pemilu (Bawaslu) dan Dewan Kehormatan Penyelenggara Pemilu (DKPP), kemudian bersepakat untuk menunda pelaksanaan Pilkada 2020. Kesepakatan ini dicapai pada Senin 30 Maret 2020 kemarin dan diikuti dengan desakan agar Presiden segera menerbitkan Peraturan Pemerintah Pengganti Undang-Undang (Perppu) untuk menjamin penundaan ini (Muhammad Aulia, 2020, hlm. 1)

Penundaan tahapan pelaksanaan Pilkada ini telah dihentikan seiring 
KHAZANAH MULTIDISIPLIN

VOL 1 NO 12020

https://journal.uinsgd.ac.id/index.php/km

dengan keluarnya Keputusan Komisi Pemilihan Umum Nomor 258/PL.02-Kpt/O1/KPU/VI/2020 tentang Penetapan Pelaksanaan Pemilihan Gubernur dan Wakil Gubernur, Bupati dan Wakil Bupati, dan/atau Wali Kota dan Wakil Wali Kota. Dilanjutkannya tahapan pelaksanaan Pilkada juga dipertegas dengan keluarnya Perpu Nomor 2 Tahun 2020 di mana dalam Pasal 201 A ayat (2) disebutkan bahwa Pelaksanan Pemungutan Suara Serentak yang diunda dilaksanakan pada Bulan Desember Tahun 2020.

Berdasarkan latar belakang masalah yang telah diuraikan di atas, maka Penulis tertarik mengidentifikasi masalah bagaimana pengaturan Pilkada Serentak Tahun 2020 dalam kondisi Corona Virus Disease 2019 (Covid- 19), serta bagaimana efektifitas penerapan aturan Pilkada Serentak 2020 dalam kondisi darurat penanganan pencegahan penyebaran Corona Virus Disease 2019 (Covid-19).

Pro dan Kontra pelaksanaan Pilkada di masa pandemi ini terus bergulir, antara kepastian hukum pengisian kekosongan jabatan Kepala Daerah juga perlindungan seluruh masyarakat terhadap penyebaran Covid-19. Maka, kajian penelitian terdahulu ini diperlukan untuk bahan acuan atau referensi dalam penentuan analisis dan penelitian. Penelitian ini terkait ektifitas pelaksanaan Pilkada Serentak Tahun 2020 dalam Kondisi Darurat Penanganan Pencegahan Penyebaran Covid- 19 dapat dilihat pada tabel 1 . 
KHAZANAH MULTIDISIPLIN

VOL 1 NO 12020

https://journal.uinsgd.ac.id/index.php/km

Tabel 1. Penelitian Terdahulu

\begin{tabular}{|c|c|c|c|}
\hline $\begin{array}{l}\text { Nama } \\
\text { Peneliti }\end{array}$ & \begin{tabular}{|l|} 
Judul \\
Penelitian
\end{tabular} & Metodologi & Hasil/Temuan Penelitian \\
\hline $\begin{array}{l}\text { Richard } \\
\text { Kennedy } \\
\& \\
\text { Bonavent } \\
\text { ura } \\
\text { Pradana } \\
\text { Suhendart } \\
\text { o (2020) }\end{array}$ & $\begin{array}{l}\text { Diskursus } \\
\text { Hukum: } \\
\text { Alternatif } \\
\text { Pola } \\
\text { Pengisian } \\
\text { Jabatan } \\
\text { Kepala } \\
\text { Daerah } \\
\text { Masa } \\
\text { Pandemi } \\
\text { Covid-19 }\end{array}$ & $\begin{array}{l}\text { Penelitian ini } \\
\text { menggunakan kualitatif. } \\
\text { pendekatan kua }\end{array}$ & $\begin{array}{l}\text { Penelitian ini memberikan } \\
\text { alternatif pola pengisian } \\
\text { jabatan Kepala Daerah di } \\
\text { masa pandemi Covid-19. Ada } \\
\text { 3 usulan pola yang } \\
\text { diajukan, yakni penunjukan } \\
\text { Penjabat sementara atau } \\
\text { Pelaksana Tugas, Pilkada tidak } \\
\text { langsung, dan Pilkada } \\
\text { menggunakan } \\
\text { elektronik. } \\
\text { Ketiga pola alternatif ini } \\
\text { memiliki kelebihan dan } \\
\text { kekurangannya masing- } \\
\text { masing, dengan disertai } \\
\text { argumentasi yuridis dan logis } \\
\text { yang kuat. }\end{array}$ \\
\hline $\begin{array}{l}\text { Aryo } \\
\text { Wasisto } \\
\& \\
\text { Prayudi } \\
\text { (2020) }\end{array}$ & $\begin{array}{l}\text { Antisipasi } \\
\text { Implikasi } \\
\text { Demokrati } \\
\text { s Pilkada } \\
\text { Serentak } \\
\text { Tahun } \\
202 O\end{array}$ & $\begin{array}{l}\text { Dalam penelitian ini } \\
\text { menggunakan metode } \\
\text { kualitatif dan kajian } \\
\text { literatur. }\end{array}$ & $\begin{array}{l}\text { Menunjukkan prakondisi } \\
\text { atas beberapa pemetaan } \\
\text { implikasi yang dapat } \\
\text { muncul terhadap } \\
\text { penyelenggaraannya di } \\
\text { lapangan. } \\
\text { 1) Kesesuaiannya } \\
\text { dengan substansi } \\
\text { Pemilu demokatis terbaik adalah } \\
\text { dengan melibatkan partisipasi } \\
\text { pemilih yang tinggi dan } \\
\text { sekaligus otonom kesadaran } \\
\text { politiknya sebagai } \\
\text { pemegang kedaulatan. } \\
\text { 2) Penegakkan aturan } \\
\text { main Pilkada yang benar-benar } \\
\text { menaati aspek keadilan dan } \\
\text { transparansi dalam setiap } \\
\text { tahapan penyelenggaraannya. } \\
\text { Oleh karena itu, KPU dan } \\
\text { Bawaslu benar-benar } \\
\text { dituntut untuk mampu } \\
\text { menjaga keseimbangan akses } \\
\text { antar peserta dan para } \\
\text { pendukungnya. }\end{array}$ \\
\hline $\begin{array}{l}\text { Erifan } \\
\text { Manulla } \\
\text { ng }\end{array}$ & \begin{tabular}{|l|} 
Pemilu \\
Legislatif \\
2014 \\
\end{tabular} & $\begin{array}{l}\begin{array}{l}\text { Penelitian ini dilakukan } \\
\text { dengan }\end{array} \\
\end{array}$ & $\begin{array}{l}\text { Hasil temuan dalam } \\
\text { penelitian ini yakni, KPU } \\
\text { Kabupaten Karo dan }\end{array}$ \\
\hline
\end{tabular}




\section{KHAZANAH MULTIDISIPLIN \\ VOL 1 NO 12020}

https://journal.uinsgd.ac.id/index.php/km

\begin{tabular}{|c|c|c|c|}
\hline & $\begin{array}{l}\text { di Daerah } \\
\text { Bencana } \\
\text { (Studi tentang } \\
\text { Jaminan Hak } \\
\text { Pilih bagi } \\
\text { Korban } \\
\text { Bencana di } \\
\text { Kabupaten } \\
\text { Karo dan } \\
\text { Sidoarjo) }\end{array}$ & $\begin{array}{l}\text { description research. } \\
\text { Sedangkan, analisis } \\
\text { data dilakukan dengan } \\
\text { reduksi data, } \\
\text { penyajian data, dan } \\
\text { penarikan kesimpulan. } \\
\end{array}$ & $\begin{array}{l}\text { Sidoarjo menjamin hak suara } \\
\text { dengan hak pilih korban } \\
\text { bencana dalam: } \\
\text { 1) Langkah yang tidak } \\
\text { terkait dengan tahapan Pemilu } \\
\text { melalui koordinasi, } \\
\text { konsolidasi, dan konsultasi. } \\
\text { 2) Langkah yang terkait } \\
\text { dengan tahapan yang berfokus } \\
\text { pada tahapan Pemilu melalui } \\
\text { penataan daerah pemilihan, } \\
\text { pemutakhiran data, dan } \\
\text { penyusunan daftar pemilih, } \\
\text { kampanye, serta pemungutan } \\
\text { suara. }\end{array}$ \\
\hline $\begin{array}{l}\text { Anto } \\
\text { nio } \\
\text { Spin } \\
\text { elli } \\
(202 \\
\text { O) }\end{array}$ & $\begin{array}{l}\text { Menyelengg } \\
\text { ar akan } \\
\text { Pemilu Di } \\
\text { Tengah } \\
\text { Pandemi } \\
\text { COVID-19: } \\
\text { Ujian } \\
\text { Krusial } \\
\text { Republik } \\
\text { Korea }\end{array}$ & $\begin{array}{l}\text { Observasi terhadap } \\
\text { penyelenggaran } \\
\text { Pemilu serta analisis } \\
\text { data. }\end{array}$ & \begin{tabular}{|lr} 
Ketika mempertimbangkan apa \\
yang perlu dipelajari dari pemilu \\
Republik Korea, negara atau \\
wilayah manapun perlu \\
mengevaluasi secara hati-hati \\
konteksnya $r$ masing-masing \\
dalam kaitannya dengan \\
prasyarat mendasar yang esensial \\
untuk menyelenggarakan pemilu \\
yang kredibel, aman dan adil di \\
tengah suatu pandemi. Bahwa \\
tidak \\
semua negara atau wilayah \\
mungkin ada di posisi yang \\
sama dan mampu untuk \\
menaati randar dan \\
pendekatan yang diperlukan \\
demi menyelenggarakan pemilu \\
yang kredibel, aman dan adil di \\
tengah pandemi COVID-19 ini. \\
Pengalaman Republik Korea \\
yang baru ini menawarkan \\
beberapa refleksi krusial dan \\
pelajaran berharga yang patut \\
didalami oleh semua negara dan \\
wilayah di dunia yang dalam \\
beberapa bulan mendatang ini \\
mencari-cari cara untuk \\
menegakkan hak demokrasi \\
rakyat secara aman..
\end{tabular} \\
\hline
\end{tabular}




\section{KHAZANAH MULTIDISIPLIN \\ VOL 1 NO 12020}

https://journal.uinsgd.ac.id/index.php/km

\begin{tabular}{|c|c|c|c|}
\hline $\begin{array}{l}\text { Herdiansy } \\
\text { ah } \\
\text { Hamzah } \\
(2020)\end{array}$ & $\begin{array}{l}\text { Pilkada vs } \\
\text { Pandemi, } \\
\text { Dan } \\
\text { Pengalaman } \\
\text { Negara Lain }\end{array}$ & 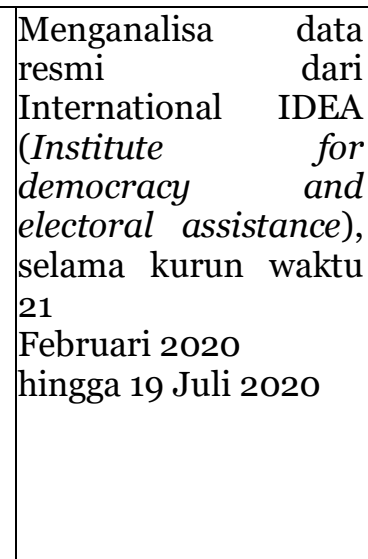 & 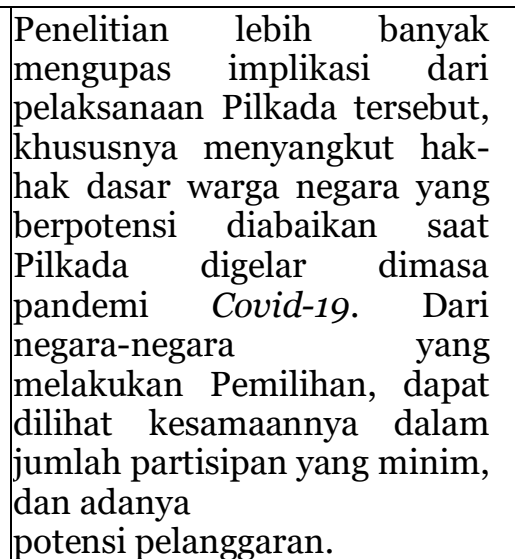 \\
\hline $\begin{array}{l}\text { Muhamm } \\
\text { ad Aulia } \\
\text { Y. } \\
\text { Guzasiah } \\
\text { (2020) }\end{array}$ & $\begin{array}{l}\text { Menimban } \\
\text { g Kembali } \\
\text { Wacana } \\
\text { Pilkada }\end{array}$ & $\begin{array}{l}\text { Analisis kebijakan ini } \\
\text { menggunakan } \\
\text { pendekatan normatif }\end{array}$ & $\begin{array}{l}\text { Disebutkan bahwa } \\
\text { penyelenggaraan Pemilu atau } \\
\text { Pilkada dengan sistem } \\
\text { elektronik atau e-voting, pada } \\
\text { dasarnya memberikan }\end{array}$ \\
\hline & $\begin{array}{l}\text { Elektroni } \\
k \quad \text { Di } \\
\text { Tengah } \\
\text { Pandemi } \\
\text { Covid-19 }\end{array}$ & 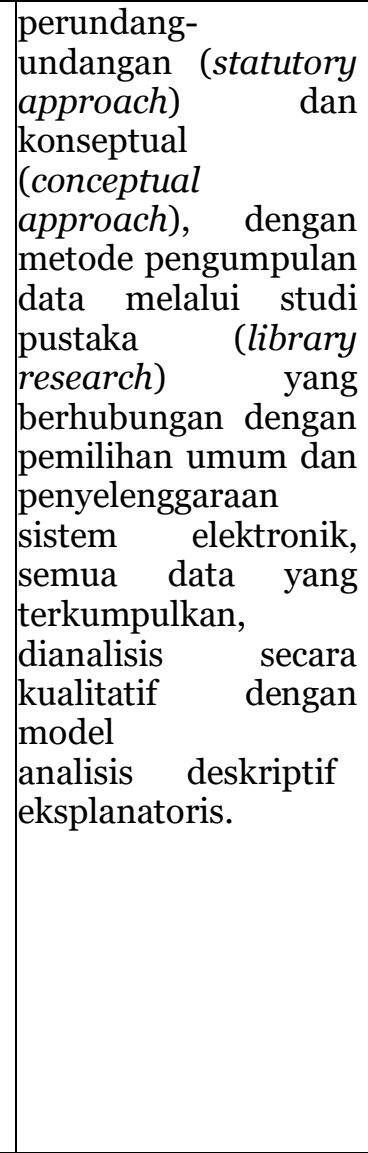 & 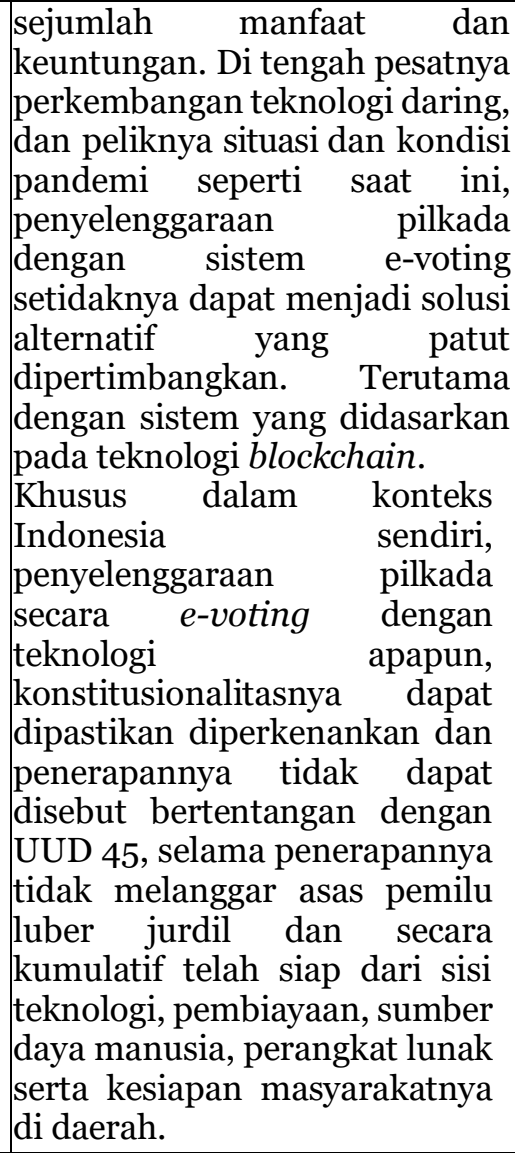 \\
\hline
\end{tabular}


KHAZANAH MULTIDISIPLIN

VOL 1 NO 12020

https://journal.uinsgd.ac.id/index.php/km

\begin{tabular}{|c|c|c|c|}
\hline $\begin{array}{l}\text { Andri } \\
\text { an } \\
\text { Habi } \\
\text { bi } \\
(202 \\
\text { O) }\end{array}$ & \begin{tabular}{|l} 
Upaya \\
Menyelamatk \\
a n Pemilihan \\
Umum Di \\
Tahun 202O
\end{tabular} & $\begin{array}{ll}\text { Analisis data Pilkada } \\
\text { dengan } & \text { metode } \\
\text { kualitatif. } & \end{array}$ & $\begin{array}{l}\text { Dengan mempertimbangkan } \\
\text { kejadian terburuk ran dan } \\
\text { kemungkinan masalah sosial, } \\
\text { ekonomi, politik, dan hukum. } \\
\text { Maka, harapan Pilkada saat } \\
\text { pandemi ran } \\
\text { membutuhkan Covid-19 } \\
\text { persatuan “menyelematkan } \\
\text { demokrasi lokal.” Pada intinya, } \\
\text { penyelamat pilkada akan } \\
\text { menjadi kebijakan dan dasar } \\
\text { hukum pada masa-masa } \\
\text { mendatang. Bukan tidak } \\
\text { mungkin, pilihan tetap pemilu } \\
\text { dalam situasi bencana dimulai } \\
\text { dari saat ini. } \\
\end{array}$ \\
\hline \begin{tabular}{|l} 
Rezky \\
Panji \\
Perdana \\
Martua \\
Hasibuan
\end{tabular} & $\begin{array}{l}\text { Urgensit } \\
\text { as Perppu } \\
\text { Pilkada } \\
\text { Di Kala } \\
\text { Wabah } \\
\text { Pande } \\
\text { mi } \\
\text { Covid- } \\
19\end{array}$ & $\begin{array}{ll}\text { Analisis data Pilkada } \\
\text { dengan } & \text { metode } \\
\text { kualitatif. } & \end{array}$ & $\begin{array}{l}\text { Berdasarakan } \\
\text { memorandum legal } \\
\text { disimpulkan bahwa negara } \\
\text { harus secara cepat dan sigap } \\
\text { untuk segera menerbitkan } \\
\text { Peraturan } \\
\text { Pengganti Undang- Undang } \\
\text { ten-tang Penundaan Pilkada. } \\
\text { Hal ini setidaknya memberikan } \\
\text { status legalitas penundaan dan } \\
\text { menjamin adanya suatu } \\
\text { kepastian hukum dalam proses } \\
\text { ketatanegaraan. }\end{array}$ \\
\hline
\end{tabular}

\section{METODE PENELITIAN}

Metode penelitian ini menggunakan kualitatif yaitu metodemetode untuk mengeksplorasi dan memahami makna yang oleh sejumlah individu atau sekelompok orang dianggap berasal dari masalah sosial atau kemanusiaan (Creswell, 2009, hlm. 465). Bogdan dan Taylor (1975, hlm. 5) berpendapat bahwa penelitian kualitatif adalah penelitian yang menghasilkan data deskriptif berupa kata-kata tertulis atau lisan dari orang-orang dan perilaku yang dapat diamati secara utuh. Sedangkan, menurut Kirk dan Miller (1986, hlm. 9) mendefinisikan penelitian kualitatif sebagai tradisi tertentu dalam ilmu pengetahuan sosial yang secara fundamental bergantung pada pengamatan pada manusia dalam kawasannya sendiri dan berhubungan dengan orang-orang tersebut.

Menurut Johnny Ibrahim (2012, hlm. 299), nilai ilmiah dari suatu pembahasan, penguraian dan penanggulangan masalah terhadap legal 
KHAZANAH MULTIDISIPLIN

VOL 1 NO 12020

https://journal.uinsgd.ac.id/index.php/km

issue atau isu masalah hukum yang diteliti, sangat tergantung kepada cara pendekatan (approach) yang digunakan oleh Penulis. Ibrahim mengatakan bahwa terdapat beberapa cara pendekatan yang dapat dilakukan oleh peneliti dalam melakukan penelitiannya berupa penelitian hukum normatif, yakni; pendekatan perundang-undangan (statue approach), pendekatan konsep (conceptual approach), pendekatan analitis (analytical approach), pendekatan perbandingan (comparativeapproach), pendekatan historis (historical approach), dan pendekatan filsafat (philosophical approach), serta pendekata kasus (case approach)”.

Berdasarkan uraian pendekatan yang disebutkan oleh sumber di atas, maka dalam artikel ini, Penulis menggunakan pendekatan perundang-undangan (statue approach). Hal tersebut dilakukan sebab penelitian hukum normatif sebagaimana yang maksud dalam artikel ini pasti terkait dengan suatu peraturan perundang-undangan tenentu. Serta, metode yang digunakan dalam penelitian ini yaitu pendekatan Yuridis Normatif.

Penajaman penelitian ini bersifat deskriftif analitis, yaitu penelitian yang berfokus pada penanggulangan masalah yang ada di masa saat ini. Penelitian yang bersifat diskriftif analitis ini dimaksudkan untuk mendeskripsikan seluruh data yang didapat, data tersebut berkaitan dengan judul penelitian secara spesifik dan detail, yang kemudian dipecahkan dan dianalisis untuk menjawab permasalahan yang ada.

Bahan-bahan hukum bersifat primer, sekunder dan tersier dipergunakan dalam penelitian ini adalah agar dapat dirumuskan satu kesimpulan dari satu bahasan tertentu yang menjadi baigan dari penelitian ini. Pada tahapan selanjutnya, kesimpulan-kesimpulan yang bersifat parsial bahasan per bahasan dapat disusun secara sistematis menjadi sebuah kesimpulan yang bersifat menyeluruh (komprehensif) yang dapat menjawab identifikasi masalah penelitian. 
KHAZANAH MULTIDISIPLIN

VOL 1 NO 12020

https://journal.uinsgd.ac.id/index.php/km

\section{HASIL DAN PEMBAHASAN}

Pengaturan Pilkada Serentak Tahun 2020 dalam kondisi Bencana Nonalam Corona Virus Disease 2019 (Covid-19)

Pemilihan Umum (Pemilu) adalah suatu proses di mana pemilih yang berasal dari masyarakat, memilih orang-orang tertentu yang telah dicalonkan Partai Politik untuk mengisi jabatan-jabatan politik tertentu. Orang-orang yang dicalonkan tersebut dipilih untuk mengisi jabatanjabatan yang beragam, seperti Presiden, wakil rakyat dipelbagai tingkat pemerintahan, sampai tingkat desa dengan dipilihnya Kepala Desa. Para masyarakat sebagai pemilih dalam Pemilu juga ikut menyaksikan komponen para peserta Pemilu. Peserta Pemilu akan menawarkan program-program unggulan serta janji-janji pada masa kampanye. Kampanye sendiri diperbolehkan dilakukan selama waktu yang telah ditentukan, yakni menjelang hari pemungutan suara.

Menurut Huda (2018, hlm. 135) setelah melakukan pemilihan, tahap berikutnya yakni pemungutan suara. Setelah pemungutan suara dilakukan, proses penghitungan suara langsung dimulai. Jika sudah, maka pemenang Pemilu akan ditentukan oleh sistem

penentuan pemenang yang sebelumnya telah disahkan dan disetujui oleh para peserta, yang sebelumnya telah disosialiasasikan ke para pemilih. Sebagaimana disebutkn oleh Mahendra (1996, hlm. 135), dalam sistem Pemilu, diketahui bahwa tidak satupun sistem yang membuat pemilih yakin terhadap siapa yang dipilihnya dan benar-benar menjamin keterwakilan masyarakat.

Selanjutnya, pengaturan Pilkada Serentak 2020 dalam kondisi bencana nonalam pandemi Covid-19:

a) Pemilihan Serentak Lanjutan dibuat dengan protokol kesehatan dalam pencegahan dan pengendalian Covid-19 dengan mempertimbakan kesehatan, keselamatan, dan keamanan penyelenggara Pemilihan, peserta Pemilihan, Pemilih, dan seluruh pihak yang terlibat dalam penyelenggaraan Pemilihan. 
KHAZANAH MULTIDISIPLIN

VOL 1 NO 12020

https://journal.uinsgd.ac.id/index.php/km

b) Aspek keselamatan dan kesehatan diberlakukan dalam seluruh tahapan dengan pemenuhan prosedur sebagai berikut:

c) Menerapkan prinsip kesehatan dan keselamatan selama kerja;

d) Melakukan rapid test atau Real Time Polymerase Chain Reaction (RT-PCR) bagi anggota dan Sekretariat Jenderal KPU, beserta anggota dan sekretariat KPU tingkat Provinsi, KPU tingkat Kabupaten/Kota, PPK, dan PPS dan/atau yang terindikasi memiliki riwayat kontak dengan orang dinyatakan terpapar Covid-19;

e) Menggunakan Alat Pelindung Diri (APD) seperti masker yang sesuai aturan, dengan menutupi hidung dan mulut hingga dagu bagi para anggota dan Sekretariat Jenderal KPU, serta anggota dan sekretariat KPU tingkat Provinsi, KPU tingkat Kabupaten/Kota, PPK, dan PPS yang sedang ditugaskan;

f) Menggunakan APD berupa sarung tangan sekali pakai, dan pelind+ung wajah (face shield) untuk:

1. PPS yang ditugaskan untuk memverifikasi faktual dukungan bagi Bakal Pasangan Calon perseorangan;

2. PPDP yang ditugaskan untuk Coklit;

3. KPPS yang ditugaskan pada Pemungutan dan Penghitungan Suara di TPS;

1. Menyediakan sarana sanitasi sesuai standar pada tempat dan/atau perlengkapan yang digunakan untuk suatu kegiatan dalam pelaksanaan tahapan penyelenggaraan Pemilihan, seperti fasilitas cuci tangan dan sabun, disinfektan, dan/atau cairan antiseptik berbahan dasar alkohol (handsanitizer);

2. Mengecek keadaan suhu tubuh semua pihak yang ikut serta dalam kegiatan sebelum kegiatan tersebut dimulai, dengan menggunakan alat yang biasa digunakan seperti thermogun agar tidak terjadinya kontak fisik, dengan 
KHAZANAH MULTIDISIPLIN

VOL 1 NO 12020

https://journal.uinsgd.ac.id/index.php/km

ketentuan suhu tubuh maksimal 37,3 derajat (tiga puluh tujuh koma tiga derajat)celcius;

3. Mengatur physical distancing seluruh pihak yang mengikuti tahapan penyelenggaraan Pemilihan dengan jarak minimal 1 (satu) meter;

4. Mengatur pelarangan berkerumun di setiap kegiatan saat berlangsungnya tahapan penyelenggaraan Pemilihan;

5. Membatasi jumlah peserta dan/atau personel yang ditanggungjawabkan dalam seluruh kegiatan pelaksanaan tahapan penyelenggaraan Pemilihan yang mengwajibkan keterlibatan anggota;

6. Membersihkan dan melakukan disinfeksi secara teratur terhadap ruangan dan peralatan yang dipakai;

7. Menghindari penggunaan peralatan atau perangkat secara bersama;

8. Memindai kesehatan hadirin yang datang dan memenuhi ruangan kegiatan; Pasal 5 Peraturan KPU RI No. 6 Tahun 2020 tentang Pelaksanaan Pemilihan Gubernur Dan Wakil Gubernur, Bupati Dan Wakil Bupati, Dan/Atau Walikota Dan Wakil Walikota Serentak Lanjutan Dalam Kondisi Bencana Nonalam Corona Virus Disease 2019 (Covid-19)

9. Menyosialisasikan, mengedukasi, mempromosikan kesehatan dan menggunakan media informasi untuk memberikan ilmu tentang pencegahan dan pengendalian penyebaran Covid-19.

\section{Pengaturan Tindakan Luar Biasa untuk Keadaan Luar Biasa}

Mengacu pada penelitian yang dilakukan Antonio Spinell, dalam makalah internasional berjudul Menyelenggarakan Pemilu di Tengah Pandemi 
KHAZANAH MULTIDISIPLIN

VOL 1 NO 12020

https://journal.uinsgd.ac.id/index.php/km

COVID-19: Ujian Krusial Republik Korea, yang dilakukan di Republik Korea. Spinell melakukan penelitian mengenai tindakan luar biasa untuk keadaan luar biasa di kala pandemi global ini. Berikut uraian metode yang Spinell (2020, hlm. 2-4) tuliskan:

1. Mendorong agar dilaksanakannya pemungutan suara lebih awal dari tanggal yang ditetapkan. Metode yang diterapkan ini guna mempersilahkan semua pemilih untuk memberikan hak suaranya sebelum tanggal yang telah diatur untuk jadwal Pemilihan. Alasan dilakukannya metode ini, yakni, agar pemilih memanfaatkan fasilitas untuk mengurangi jumlah pemilih menumpuk pada hari Pemilihan yang sebenarnya.

2. Memperbolehkan pemungutan suara dilakukan dari rumah dengan pemanfaatan pos. Metode ini dilakukan terutama bagi pasien positif Covid-19 yang berada di rumah sakit, rumah karantina, ataupun pusat layanan kesehatan.

3. Memastikan lingkungan yang didatangi aman untuk memilih. Perlu adanya sistem aturan ketat dalam metode ini untuk memastikan lingkungan tempat memilih dan pemungutan suara sudah aman. Hal tersebut diupayakan untuk mengurasi resiko penularan Covid-19.

4. Menjaga komunikasi dengan publik. Spinell menjelaskan cara efektif berkomunikasi dengan khalayak ramai yaitu melalui saluran televisi nasional, serta menyebarkan poster dan spanduk di tempattempat yang banyak didatangi masyarakat.

5. Menjaga keterbukaan proses pemungutan dan penghitungan suara dengan cara menyiarkan langsung proses penghitungan suara. Jika dalam Pemilihan 
KHAZANAH MULTIDISIPLIN

VOL 1 NO 12020

https://journal.uinsgd.ac.id/index.php/km

sebelumnya penghitungan suara dilaksankan di tempat berlangsungnya pemungutan suara. Namun, dalam kondisi darurat seperti ini, penghitungan dapat ditampilkan di saluran siaran langsung, agar masyarakat masih tetap bisa menyaksikan.

6. Beradaptasi dengan metode kampanye. Tentu, peserta politik pun menyadari keterbatasan dalam berkampanye. Maka, dianjurkannya kampanye berbasis daring dengan menggunakan beragam teknologi yang andal, agar proses kampanye masih bias berlangsung dana terasa dampaknya.

\section{Pembelajaran Pilkada Saat Situasi Pandemi dari Negara Lain}

Herdiansyah Hamzah dalam jurnal berjudul Pilkada vs Pandemi, dan Pengalaman Negara Lain telah mendeskripsikan beberapa hal yang menjadi poin penting pelaksanaan Pilkada dikala pandemi. Dikutip dari Hamzah (2020, hlm. 1) berdasakan data yang diperoleh dari International Institute for Democracy and Electoral Assistance (IDEA), disebutkan bahwa sejak 21 Februari 2020 hingga 19 Juli 2020, setidaknya ada 67 negara dan wilayah teritori yang telah memutuskan penundaan Pemilu Nasional dan Subnasional akibat terjadinya pandemi Covid-19. Dari 67 negara tersebut, setidaknya terdapat 23 negara yang menetapkan menunda Pemilu dan Referendum Nasional. Namun pada periode yang sama, ada 49 negara yang meimilih tetap melaksanakan Pemilu Nasional dan Subnasional sebagaimana telah direncanakan matang-matang sebelumnya. Darijumlah tersebut, setidaknya 31 negara sudah melakukan Pemilu atau Referendum Nasional, meskipun diselimuti kekhawatiran dan kecemasan. Selanjutnya, dari 49 negara yang disebutkan di atas, Penulis dapat melihat pembelajaran untuk diterapkan dalam penyelenggaraan Pilkada di Indonesia, diantaranya:

1. Kondisi dengan minimnya partisipasi dan respon warga negara yang berstatus sebagai pemilih. Hal tersbut menjadi tugas 
KHAZANAH MULTIDISIPLIN

VOL 1 NO 12020

https://journal.uinsgd.ac.id/index.php/km

pemerintah untuk memberikan rasa aman dan nyaman bagi masyarakat yang mempertimbangan kesediaannya dalam memenuhi hak suara. Berdasarkan data yang dihimpun dari International IDEA, tingkat partisipasi pemilih di negara-negara yang memutuskan untuk tetap menyelenggarakan pemilihan di masa pandemi ini mengalami penurunan yang sginifikan. Sebagai contoh negara Iran dalam Pemilu sebelumnya berhasil menggaet partisipan sebanyak 60,09\%, tapi di tahun ini turun ke angka 42,32\%.

2. Mengacu pada negara yang dianggap berhasil menyelenggarakan Pemilu meskipun dalam kondisi pandemi, seperi negara Korea Selatan dan Polandia. Partisipan pemilih di Korea Selatan mencapai angka $66,21 \%$ dari total 43.994 .247 pemilih yang terdaftar. Angka tersebut dianggap sebagai kemajuan dari Pemilu sebelumnya di tahun 2016 yang hanya menari partisipan sebanyak 58,03\%. Peningkatan angka partisipan pun dialami oleh negara Polandia, pada putaran pertama di tanggal 28 Juni 2020 dan putara kedua di tanggal 12 Juli 2020, total partisipan dalam putaran tersebut sebanyak 68,18\% dari 30.268.543 pemilih terdaftar. Dibandingkan pda Pemilu sebelumnya di tahun 2015, jumlah partisipan di Polandia hanya 55,34\%.

3. Potensi pelanggaran dalam penyelenggaraan Pilkada di masa pandemi Covid-19 sangat bias terjadi, terutama jika penyelenggara telah memikirkan sebelumnya.

Adapun yang dapat diprediksi dari potensi pelanggaran yang akan terjadi, diantaranya ialah adanya pragmatisme politik, terdapat ancaman keselamatan bagi masyarakat, hal ini berkaitan dengan kondisi yang mengancam hak pilih masyarakat, dikhawatirkan akan menguntungkan pertahana, serta adanya poilitisasi bansos penanganan Covid-19. 
KHAZANAH MULTIDISIPLIN

VOL 1 NO 12020

https://journal.uinsgd.ac.id/index.php/km

\section{Efektifitas penerapan aturan Pilkada Serentak 2020 dalam kondisi Nonalam Corona Virus Disease 2019 (Covid-19).}

Pilkada merupakan perwujudan dan konsekuensi dari hak otonomi yang diberikan kepada rakyat daerah untuk mempunyai pemerintahan daerah sendiri sesuai dengan UUD 1945. Tanpa ada pemilihan kepala daerah oleh rakyat langsung maupun tidak langsung maka tidak ada otonomi daerah. Pilkada muncul dalam konsep fix term executive (sistem presidensial), dimana kepala pemerintahan tidak otomatis dijabat oleh ketua partai politik (koalisi) pemenang pemilu dalam sistem parlementer.

Dalam Khairi (2020), Pilkada berkualitas akan diukur dari:

A. Proses Pilkada Harus Luber dan Jurdil. Adil baik pada sisi pemilih maupun sisi calon yang dipilih.

B. Tersedianya informasi yang utuh tentang calon yang akan dipilih, tidak hanya program, namun yang jauh lebih penting adalah catatan integritas dan kapabilitasnya. Kampanye yang hanya mengedepankan program kerja calon berpotensi melahirkan calon yang korup. Oleh karena itu, mengekspos seluruh sisi "baik" dan sisi "buruk" dari calon menjadi salah satu hal penting dalam memilih pemimpin yang berintegritas.

C. Terpilihnya pemimpin yang mempunyai kapabilitas dan kredibilitas.

Selain berkualitas, Pilkada juga harus mempunyai legalitas yang diukur dari:

A. Terpenuhinya seluruh ketentuan dalam penyelenggaraan pemilihan kepala daerah.

B. Rendahnya sengketa antara penyelenggara dan peserta pilkada.

Sisa Waktu yang hanya kurang dari 4 bulan apakah memungkinkan 
KHAZANAH MULTIDISIPLIN

VOL 1 NO 12020

https://journal.uinsgd.ac.id/index.php/km

seluruh tahapan Pilkada dilaksanakan secara utuh. Penyederhanaan tahapan pilkada tidak boleh mengurangi "fairness", hak pemilih dan calon, validitas data, transparansi, dan aspek mendasar lainnya dalam melindungi hak-hak warga negara.

Kampanye adalah ajang interaksi antara pemilih dengan Paslon Kepala Daerah untuk saling mengenal dan saling mempengaruhi. Pendidikan masyarakat Indonesia yang masih

mencapai 61\% dengan pendidikan SMP ke bawah, kampanye masih sangat bergantung pada metode interaksi langsung dan melalui media kompensional. Kondisi pandemi sangat membatasi terjadinya komunikasi langsung antara Paslon dengan Pemilih.

Dalam suasana pengendalian wabah Covid-19 banyak dilakukan pembatasan kontak langsung, Kampanye yang terbatas dapat memberikan keuntungan berganda pada petahana, selain sudah dikenal luas, juga dapat melakukan interaksi dengan mengatasnamakan kegiatan jabatan yang tidak turut dibatasi. Sementara paslon nonpetahana akan mendapati banyak pembatasan sesuai dengan Protokol Pengendalian Covid-19. Pembatasan atas nama pengendalian Covid-19 akan sangat berpotensi untuk dimanfaatkan oleh Petahana untuk membatasi interkasi Paslon lain. Maka hal ini akan berpotensi melahirkan ketidakadilan (unfairness) yang juga berpotensi melanggar azas pilkada Jurdil.

Membandingkan Korea Selatan dan Indonesia, meskipun secara Global masih dalam status Pandemi Covid-19, namun korea selatan sudah dapat mengendalikan Pandemi di negaranya pada bulan Maret 2020 dengan melakukan testing massif dan gratis sebanyak

10.000 orang perhari sejak 20 Januari 2020 di Kota Seoul dengan penduduk hanya 10 jt. Sehingga Pemilu Korea Selatan sesungguhnya dilakukan pada saat Pandemi sudah terkendali dengan Kasus Baru antara dibawah 50 orang setiap harinya sejak Maret dan tanggal 8 Juni hanya 38 orang. Semua kasus mampu dilacak (tracing) secara efektif. Indonesia saat ini masih jauh dari terkendali, bahkan dalam 3 hari terahkhir kasus 
KHAZANAH MULTIDISIPLIN

VOL 1 NO 12020

https://journal.uinsgd.ac.id/index.php/km

baru semakin meningkat dan barada pada jumlah kasus harian tertinggi selama pandemi. Kesadaran dan kepatuhan terhadap Protokol kesehatan di Indonesia masih jauh dibawah Korea Selatan.Kondisi seperti ini akan berpotensi mengakibatkan Pilkada menjadi salah satu pintu penularan Covid-19.

Hampir semua daerah mengalami penurunan pendapatan secara signifikan. Di sisi lain kebutuhan anggaran menjadi membengkak untuk dana darurat penanagan Covid-19. Alokasi dana untuk Pilkada akan menyedot anggaran sekitar 15 Trilyun (Kapuspen Kemendagri, Kompas. 7/2/2020). Anggaran tersebut dapat berkontribusi secara signifikan dalam mengatasi wabah Covid-19.

Pilkada 2020 diperlukan untuk mengisi Kekosongan Kepala Daerah hasil Pilkada 2015 yang akan berakhir antara februari sampai November 2021. Jika Pilkada tidak digelar pada tahun 2020 dan sampai akhir 2021 belum terpilih Kapala Daerah baru, maka 270 Kepala Daerah kosong dan harus diisi dengan Penjabat Kepala Daerah.

\section{SIMPULAN}

Dalam segala hal prinsip keselamatan masyarakat harus dikedepankan bahkan di atas azas prinsip pemilihan. Penyelenggaraan Pemilihan Kepala Daerah yang berkualitas tidak berjalan lurus dengan hasil pemimpin yang berkualitas, untuk itu prioritas kesehatan masyarakat dalam Pemilihan Serentak Tahun 2020 dalam kondisi wabah Covid-19 harus menjadi prioritas.

Oleh karena itu, perlu dilakukan simulasi multi aspek secara komperenhensif terhadap pelaksanaan Pilkada jika digelar Desember 2020. Jika hasil simulasi multi aspek dan prediksi pengendalian pandemi akan membaik pada akhir 2020, sebaiknya Pilkada dapat diundur pada pertengahan 2021, dan untuk beberapa Kepala Daerah yang habis masa jabatannya ditunjuk Penjabat.

\section{DAFTAR PUSTAKA}

Antonio Spinell. (2020) Menyelenggarakan Pemilu di Tengah 
KHAZANAH MULTIDISIPLIN

VOL 1 NO 12020

https://journal.uinsgd.ac.id/index.php/km

Pandemi COVID-19: Ujian Krusial Republik Korea, Makalah

Teknik Internasional IDEA 2/2020, April 2020, DOI: 10.31752/idea.2020.17

Aryo Wasisto \& Prayudi. (2020) Antisipasi Implikasi Demokratis

Pilkada Serentak Tahun 202O, Bidang Politik dalam Negeri:

Info Singkat Kajian Singkat Terhadap Isu Aktual Dan

Strategis, Vol. XII, No.12/II/Puslit/Juni/2020, Juni 2020

Creswell.(2016) Research Design: Qualitative, Quantitative, and Mixed Methods Approaches.

Erifan Manullang (2015), Pemilu Legislatif 2014 di Daerah Bencana

(Studi tentang Jaminan Hak Pilih bagi Korban Bencana di

Kabupaten Karo dan Sidoarjo)

Khairi ,Halilul. (2020), Kebijakan Pilkada Dimasa Pandemi, (Jakarta:

LPM IPDN, 2020)

Herdiansyah Hamzah, Pilkada vs Pandemi, Dan Pengalaman Negara

Lain, Agustus 2020

Johnny Ibrahim, Teori \& Metodologi Penelitian Hukum Normatif,

(Bayumedia Publishing,Malang, 2012)

Kirk, J. \& Miller, M. L., Reliability and Validity in Qualitative Research.

Beverly Hills: Sage Publications, 1986

Muhammad Aulia Y. Guzasiah, Menimbang Kembali Wacana Pilkada

Elektronik Di Tengah Pandemi Covid-19, The Indonesian

Institute Center for Public Policy Research, Juni 2020

Rezky Panji Perdana Martua Hasibuan, Urgensitas Perppu Pilkada Di

Kala Wabah Pandemi Covid-19, ADALAH Buletin Hukum \&

Keadilan Vol. 4 No. 1, 2020, DOI: 10.15408/adalah.v4i1.15503

Richard Kennedy \& Bonaventura Pradana Suhendarto, Diskursus

Hukum: Alternatif Pola Pengisian Jabatan Kepala Daerah di

Masa Pandemi Covid-19, Jurnal Pembangunan Hukum

Indonesia Volume 2 Nomor 2, 2020

Robert Bogdan \& Taylor Steven J. Introduction to Qualitative Research 
KHAZANAH MULTIDISIPLIN

VOL 1 NO 12020

https://journal.uinsgd.ac.id/index.php/km

Methods. USA: A Wiley-Interscience Publication, 1975

Uu Nurul Huda, Hukum Partai Politik Dan Pemilu di Indonesia,

(Bandung:Fokus Media, 2018)

Yusril Ihza Mahendra, Dinamika Tatanegara Indonesia, (Jakarta:Gema insani Press,1996) 